\title{
Arsenic Exposure Induces Unscheduled Mitotic S Phase Entry Coupled with Cell Death in Mouse Cortical Astrocytes
}

\author{
Nang T. T. Htike ${ }^{1}$, Fumihiko Maekawa ${ }^{2}$, Haruka Soutome ${ }^{1}$, Kazuhiro Sano ${ }^{2}$, Sho Maejima ${ }^{3}$, \\ Kyaw H. Aung ${ }^{1}$, Masaaki Tokuda ${ }^{4}$ and Shinji Tsukahara ${ }^{1,3 *}$ \\ ${ }^{1}$ Area of Regulatory Biology, Division of Life Science, Graduate School of Science and Engineering, Saitama University, \\ Saitama, Japan, ${ }^{2}$ Center for Health and Environmental Risk Research, National Institute for Environmental Studies, Tsukuba, \\ Japan, ${ }^{3}$ Area of Life-NanoBio, Division of Strategy Research, Graduate School of Science and Engineering, Saitama \\ University, Saitama, Japan, ${ }^{4}$ Department of Cell Physiology, Faculty of Medicine/Graduate School of Medicine, Kagawa \\ University, Kagawa, Japan
}

OPEN ACCESS

Edited by:

Eric W. Roubos,

Radboud University Nijmegen,

Netherlands

Reviewed by:

Francisco Capani,

University of Buenos Aires (UBA) and National Scientific and Technical Research Council (CONICET),

Argentina

Remco H. S. Westerink Utrecht University, Netherlands

*Correspondence: Shinji Tsukahara stsuka@mail.saitama-u.ac.jp

Specialty section: This article was submitted to Neuroendocrine Science, a section of the journal Frontiers in Neuroscience

Received: 09 February 2016 Accepted: 13 June 2016

Published: 29 June 2016

Citation:

Htike NTT, Maekawa F, Soutome H,

Sano K, Maejima S, Aung KH,

Tokuda M and Tsukahara S (2016)

Arsenic Exposure Induces Unscheduled Mitotic S Phase Entry

Coupled with Cell Death in Mouse Cortical Astrocytes.

Front. Neurosci. 10:297. doi: 10.3389/fnins.2016.00297
There is serious concern about arsenic in the natural environment, which exhibits neurotoxicity and increases the risk of neurodevelopmental disorders. Adverse effects of arsenic have been demonstrated in neurons, but it is not fully understood how arsenic affects other cell types in the brain. In the current study, we examined whether sodium arsenite $\left(\mathrm{NaAsO}_{2}\right)$ affects the cell cycle, viability, and apoptosis of in vitro-cultured astrocytes isolated from the cerebral cortex of mice. Cultured astrocytes from transgenic mice expressing fluorescent ubiquitination-based cell cycle indicator (Fucci) were subjected to live imaging analysis to assess the effects of $\mathrm{NaAsO}_{2}(0,1$, 2 , and $4 \mu \mathrm{M}$ ) on the cell cycle and number of cells. Fucci was designed to express monomeric Kusabira Orange2 (mKO2) fused with the ubiquitylation domain of hCdt1, a marker of $\mathrm{G} 1$ phase, and monomeric Azami Green (mAG) fused with the ubiquitylation domain of hGem, a marker of $\mathrm{S}, \mathrm{G} 2$, and $\mathrm{M}$ phases. $\mathrm{NaAsO}_{2}$ concentration-dependently decreased the peak levels of the $\mathrm{mAG} / \mathrm{mKO} 2$ emission ratio when the ratio had reached a peak in astrocytes without $\mathrm{NaAsO}_{2}$ exposure, which was due to attenuating the increase in the mAG-expressing cell number. In contrast, the $\mathrm{mAG} / \mathrm{mKO} 2$ emission ratio and number of mAG-expressing cells were concentration-dependently increased by $\mathrm{NaAsO}_{2}$ before their peak levels, indicating unscheduled $S$ phase entry. We further examined the fate of cells forced to enter $\mathrm{S}$ phase by $\mathrm{NaAsO}_{2}$. We found that most of these cells died up to the end of live imaging. In addition, quantification of the copy number of the glial fibrillary acidic protein gene expressed specifically in astrocytes revealed a concentration-dependent decrease caused by $\mathrm{NaAsO}_{2}$. However, $\mathrm{NaAsO}_{2}$ did not increase the amount of nucleosomes generated from DNA fragmentation and failed to alter the gene expression of molecules relevant to unscheduled $S$ phase entry-coupled apoptosis (p21, p53, E2F1, E2F4, and Gm36566). These findings suggest that $\mathrm{NaAsO}_{2}$ adversely affects the cell cycle and viability of astrocytes by inducing unscheduled $\mathrm{S}$ phase entry coupled with cell death that may be caused by mechanisms other than apoptosis.

Keywords: astrocytes, sodium arsenite, cell cycle, cell death, live imaging 


\section{INTRODUCTION}

Several environmental chemicals are suspected to exert deleterious effects on development of the brain, which may result in an increased risk of neurodevelopmental disorders such as autism, attention-deficit hyperactivity disorder, and cerebral palsy (Grandjean and Landrigan, 2006, 2014). Arsenic is one of these environmental toxicants that disrupt brain development. According to a long-term prospective study of survivors of arsenic poisoning from the Morinaga milk incident in Japan, arsenic poisoning during infancy leads to a risk of mortality from neurological diseases in adulthood (Tanaka et al., 2010). Epidemiological studies suggest that chronic consumption of arsenic-contaminated water causes a reduction in the cognitive performance of school-age children (Calderon et al., 2001; Tsai et al., 2003; Wasserman et al., 2007). Thus, arsenic exposure via drinking water may be a risk factor for neurodevelopmental disorders.

Animal studies support the notion that developmental exposure to arsenic increases the risk of neurodevelopmental disorders. Exposure to sodium arsenite $\left(\mathrm{NaAsO}_{2}\right)$, an inorganic arsenical compound, via drinking water during gestational and/or postnatal periods causes impairment of spatial learning and memory, neuromotor reflex alteration, and spontaneous locomotor deficits in adult rats (Rodriguez et al., 2002; Xi et al., 2009). Offspring of female mice, which had been chronically exposed to $\mathrm{NaAsO}_{2}$ via drinking water, display depression-like behavior (Martinez et al., 2008), and exhibit deficits in a hippocampus-dependent learning tasks (MartinezFinley et al., 2009) during adulthood. Thus, $\mathrm{NaAsO}_{2}$ exposure during developmental periods and the associated adverse effects on brain development induce behavioral abnormalities, although the toxic mechanisms of arsenic remain to be elucidated.

In vitro studies of neurons have revealed that $\mathrm{NaAsO}_{2}$ induces apoptotic cell death in primary cultured neurons (Namgung and Xia, 2001; Wong et al., 2005) and neuronal cell lines (Koike-Kuroda et al., 2010; Keim et al., 2012). In addition, $\mathrm{NaAsO}_{2}$ disrupts neuritogenesis in primary cultured neurons (Maekawa et al., 2013) and neuronal cell lines (Frankel et al., 2009; Aung et al., 2013). We previously reported that $\mathrm{NaAsO}_{2}$ induced apoptosis is mediated by activation of caspase-3 (KoikeKuroda et al., 2010), and that inhibition of neuritogenesis by $\mathrm{NaAsO}_{2}$ is caused by alterations in the expression of cytoskeletal genes tau, tubulin, and neurofilament (Aung et al., 2013), and suppression of glutamate AMPA receptor expression (Maekawa et al., 2013). The toxic mechanisms by which developmental exposure to $\mathrm{NaAsO}_{2}$ impairs the aforementioned brain functions and behaviors remain to be uncovered. However, based on in vitro studies of neurons, inorganic arsenic adversely affects the fate and maturation processes of young neurons, which may lead to abnormal formation of the neural circuits responsible for the brain functions and behaviors.

In addition to neurons, there may be other target cells of arsenic in the developing brain. Astrocytes are the largest population of glial cells, which are more abundant in the brain compared with neurons, and contribute to the formation and maintenance of the blood-brain barrier (BBB). The $\mathrm{BBB}$ is composed of endothelial cells, which line capillary blood vessels and connect to each other via tight junctions, and astrocytes surrounding blood capillaries via their end feet (Abbott, 2002). The BBB is not considered as a perfect barrier, although it contributes to protection of the brain against circulating xenobiotics that disrupt brain functions. The developing brain is considered to be vulnerable to toxic chemicals compared with the adult brain. One of the reasons is that the immature BBB during early development provides only partial protection against entry of chemicals into the brain (Zheng et al., 2003). Arsenite and arsenate are transferred to offspring through the placenta of pregnant mice that are exposed via drinking water, and arsenic species easily crossing the immature $\mathrm{BBB}$ accumulate in the brains of newborn offspring (Jin et al., 2006). Astrocytes are therefore the first brain cells that appear to be targeted by inorganic arsenic when it is transferred from the blood to the brain. Arsenite inhibits glutamate metabolism in astrocytes by reducing the activity and expression of glutamine synthase and glutamate transporters (Zhao et al., 2012). Synapse formation of primary cultured neurons is impaired by culture in conditioned medium from arsenite-exposed astrocytes (Wang et al., 2013). Taken together, the neurotoxicity of inorganic arsenic may be, at least in part, caused by its effects on astrocytes.

During brain development, neuron generation occurs first, followed by the generation of glial cells. In the cerebral cortex of rodents, astrocyte generation begins on embryonic day 18 following neurogenesis during embryonic days $12-18$, and the number of astrocytes peaks in the neonatal period (Miller and Gauthier, 2007). It is assumed that neurotoxicant exposure during the developmental period affects not only neurogenesis but also the generation and proliferation of astrocytes, followed by altering the cell numbers. A reduced number of cortical glial cells is related to the pathological changes of schizophrenia and depression, indicating a causal link between glial cell abnormalities and psychiatric disorders (Cotter et al., 2001). In primary cultured rat astrocytes, inorganic arsenic decreases cell viability and increases DNA damage (Catanzaro et al., 2010). Such toxic effects of arsenite are stronger than those of arsenate (Jin et al., 2004). However, the mechanisms by which inorganic arsenic reduces the viability of astrocytes are largely unknown. Fluorescent ubiquitination-based cell cycle indicator (Fucci), which consists of monomeric Kusabira Orange2 (mKO2) fused with the ubiquitylation domain of human Cdt1 to monitor G1 phase and monomeric Azami Green (mAG) fused with the ubiquitylation domain of human Geminin to monitor S/G2/M phases, is useful to visualize the dynamics of cell cycle progression (Niwa et al., 1991; Sakaue-Sawano et al., 2008). In this study, we carried out live imaging analysis of primary cultured astrocytes originating from the cerebral cortex of Fucci transgenic (tg) mice to determine whether $\mathrm{NaAsO}_{2}$ exposure decreases cell viability by affecting the cell cycle. Additionally, we examined the effects of $\mathrm{NaAsO}_{2}$ exposure on the viability, apoptotic cell death, and expression of genes related to the cell cycle and apoptosis in cultured cortical astrocytes. 


\section{MATERIALS AND METHODS}

\section{Animals}

Fucci tg mice were bred and maintained at the National Institute for Environmental Studies (Tsukuba, Japan). Wildtype C57BL/6J mice (Sankyo Labo Service, Tokyo, Japan) were bred at Saitama University (Saitama, Japan). They were housed under a controlled temperature $\left(23 \pm 2^{\circ} \mathrm{C}\right)$ and photoperiod (12:12, light:dark) with free access of tap water and standard chow. Animal procedures were conducted according to the approval and guidelines of Animal Care and Use Committee at the National Institute of Environmental Studies and Saitama University.

\section{In vitro Culture of Astrocytes}

Fucci tg and C57BL/6J mice were sacrificed on postnatal days 1 or 2 (postnatal day $1=$ day of birth). After isolation of the cerebral cortex from the brain, the meninges were removed and the cortex tissue were placed in ice-cold Dulbecco's modified Eagle's medium (Sigma-Aldrich, St. Louis, MO, USA) supplemented with $3.7 \mathrm{mg} / \mathrm{L}$ sodium bicarbonate (SigmaAldrich), $10 \mathrm{~mL} / \mathrm{L}$ antibiotic antifungal solution (Sigma-Aldrich), which contained 10,000 units penicillin, $10 \mathrm{mg}$ streptomycin, and $25 \mu \mathrm{g}$ amphotericin B per $\mathrm{mL}$, and $10 \%$ fetal bovine serum (FBS; Gibco-Invitrogen, Carlsbad, CA, USA), which is hereafter referred to as culture medium ( $\mathrm{pH}$ 7.2). Cells were isolated from the cerebral cortex in fresh culture medium by gentle mechanical trituration, seeded on poly-L-ornithine $(15 \mu \mathrm{g} / \mathrm{L})$ precoated culture dishes or plates, and maintained in culture medium at $37^{\circ} \mathrm{C}$ in a humidified atmosphere with $5 \% \mathrm{CO}_{2}$. The culture medium was changed at 3 days after seeding, followed by medium changes at intervals of 3-4 days.

Cells obtained from Fucci tg mice were seeded on a four-compartment glass bottom dish (Greiner Bio-One, Kremsmünster, Austria) at $1 \times 10^{5}$ cells per compartment $\left(1.9 \mathrm{~cm}^{2}\right)$, cultured for more than 1 week, and then applied to fluorescence microscopy (see Section Fluorescence Microscopy of Fucci-Expressing Astrocytes) and live imaging analyses (see Section Time-Lapse Analysis of Fucci-Expressing Astrocytes). Cells obtained from C57BL/6J mice were seeded on a 6-well culture plate (Asahi Glass, Tokyo, Japan) at $3 \times 10^{5}$ cells per well $\left(9.4 \mathrm{~cm}^{2}\right)$ and cultured until $90-100 \%$ confluence. The cells were re-seeded onto new culture plates at $1 \times 10^{5}$ cells per well after trypsinization and then used to analyze the protein expression of glial fibrillary acidic protein (GFAP), a marker of astrocytes (see Section Analysis of GFAP Immunoreactivity), and the GFAP gene copy number (see Section Analysis of GFAP Gene Copy Numbers). For gene expression analysis (see Section Analysis of mRNA Levels), the cells were re-seeded at $4 \times 10^{5}$ cells per well after trypsinization. For apoptosis analysis, the cells were re-seeded on a 96-well culture plate (Asahi glass) at $5 \times 10^{3}$ cells per well (see Section Apoptosis Assay). All culture dishes and plates were precoated with poly-L-ornithine $(15 \mu \mathrm{g} / \mathrm{L})$ before use.

\section{Analysis of GFAP Immunoreactivity}

To check the purity of cells in primary culture, we performed immunocytochemistry of GFAP. Cultured cells fixed with $4 \%$ paraformaldehyde were reacted with a polyclonal rabbit antiGFAP antibody (1:500; Dako, Glostrup, Denmark) at $4^{\circ} \mathrm{C}$ overnight and then Alexa Fluor 647 goat anti-rabbit IgG (1:400; Life Technology, Carlsbad, CA, USA) for $30 \mathrm{~min}$ at room temperature. 4,6-Diamidino-2-phenylindole (DAPI) staining was performed to count the total cell number.

\section{Fluorescence Microscopy of Fucci-Expressing Astrocytes}

To determine the cell cycle duration of astrocytes, we observed astrocytes from Fucci tg mice under a fluorescence microscope (BioZero 8100; Keyence, Osaka, Japan) equipped with an mKO2 filter (excitation filter: 542AF15; emission filter: 585QM30; dichroic mirror: 560 DRLP; Opto science, Tokyo, Japan) and a mAG filter (excitation filter: 475QM20; emission filter: 518QM32; dichroic mirror: 500DRLP; Opto science). First, the cell cycle of each astrocyte was synchronized by serum starvation. Culturing in medium supplemented with a low concentration of FBS $(0.5 \%)$ for $72 \mathrm{~h}$ is effective to increase the population of cells at G1 phase (Khammanit et al., 2008). Therefore, $30-40 \%$ confluent astrocytes were incubated in culture medium supplemented with $0.1 \%$ FBS for 3 days. The astrocytes were again incubated in culture medium containing $10 \% \mathrm{FBS}$, and fluorescence images of $\mathrm{mKO} 2$ and $\mathrm{mAG}$ were captured every $6 \mathrm{~h}$ for $150 \mathrm{~h}$ using an objective lens (Plan Fluor ELWD DM $20 \times$ C, NA 0.45; Nikon, Tokyo, Japan) and a CCD camera in the BioZero 8100 fluorescence microscope. In each culture, digital images were obtained in three regions $\left(0.58 \mathrm{~mm}^{2} /\right.$ region, $1.74 \mathrm{~mm}^{2}$ in total) that were randomly selected in the culture dish. Fluorescence microscopy was performed in four primary cultures derived from different animals.

Image analysis of $\mathrm{mKO} 2$ and $\mathrm{mAG}$ expression was performed with BZ-II analyzer software (Keyence). The digital images were modified to remove the background signal, and the red-greenblue (RGB) digital images of $\mathrm{mKO} 2$ and $\mathrm{mAG}$ were converted to monochromatic color images (red, $\mathrm{mKO} 2$; green, $\mathrm{mAG}$ ). The monochromatic color images of $\mathrm{mKO} 2$ and $\mathrm{mAG}$ were merged at each time point to determine the intensities of $\mathrm{mKO} 2$ and $\mathrm{mAG}$ expression in the same region, which were obtained by measuring the brightness of the red and green signals, respectively. After measuring the brightness values of red and green signals in the same region of each merged image, the $\mathrm{mAG} / \mathrm{mKO} 2$ emission ratio was calculated by dividing the brightness value of the green signal by that of the red signal. The $\mathrm{mAG} / \mathrm{mKO} 2$ emission ratio at each time point was calibrated using the ratio of the same area at $0 \mathrm{~h}$ after the end of serum starvation, which was set at 100 .

\section{Time-Lapse Analysis of Fucci-Expressing Astrocytes \\ Exposure to $\mathrm{NaAsO}_{2}$ and Live Imaging}

$\mathrm{NaAsO}_{2}$ (Wako Pure Chemical Industries, Osaka, Japan) was dissolved in sterile-filtered water (Sigma-Aldrich) at a concentration of $100 \mathrm{mM}$. The $\mathrm{NaAsO}_{2}$ solution $(100 \mathrm{mM})$ was further diluted with culture medium to obtain the indicated concentrations. Primary cultured Fucci-expressing astrocytes were subjected to serum starvation (see Section Fluorescence Microscopy of Fucci-Expressing Astrocytes) to synchronize the 
cell cycle. After synchronization, the cells were exposed to $\mathrm{NaAsO}_{2}$ in culture medium at concentrations of $0,1,2$, or $4 \mu \mathrm{M}$. Immediately after starting $\mathrm{NaAsO}_{2}$ exposure, astrocytes were placed in an incubation chamber (Tokai Hit, Shizuoka, Japan) equipped to the BioZero 8100 fluorescence microscope. In the incubation chamber, the temperature was controlled at $37^{\circ} \mathrm{C}$ and the $\mathrm{CO}_{2}$ concentration was maintained at $5 \%$. Timelapse fluorescence imaging began at $1 \mathrm{~h}$ and ended at $73 \mathrm{~h}$ after initiation of $\mathrm{NaAsO}_{2}$ exposure. Fluorescence images of mKO2 and $\mathrm{mAG}$ expression, and bright field images were captured every $2 \mathrm{~h}$. The digital image data were obtained from three regions $\left(0.58 \mathrm{~mm}^{2} /\right.$ region, $1.74 \mathrm{~mm}^{2}$ in total $)$ that were randomly selected in each culture dish compartment. Live imaging of Fucciexpressing astrocytes was performed in six primary cultures derived from different animals.

\section{Image Analysis}

We analyzed the intensity of $\mathrm{mKO} 2$ and $\mathrm{mAG}$ signal emissions, the number of cells expressing $\mathrm{mKO} 2$ and $\mathrm{mAG}$, and the cell fate after $S$ phase entry using the digital image data from live imaging. Image analyses were performed using the BZ-II analyzer software. The images were modified to remove the background signal and change the RGB colors of $\mathrm{mKO} 2$ and $\mathrm{mAG}$ to monochromatic colors. The modified images were used for analysis as described below.

The monochromatic color images of $\mathrm{mKO} 2$ (red) and $\mathrm{mAG}$ (green) were merged at each time point to measure the intensities of $\mathrm{mKO} 2$ and $\mathrm{mAG}$ in the same region, which were obtained by measuring the brightness of red and green signals, respectively. The $\mathrm{mAG} / \mathrm{mKO} 2$ emission ratio was then calculated by dividing the brightness value of the green signal by that of the red signal. The $\mathrm{mAG} / \mathrm{mKO} 2$ emission ratio at each time point was calibrated using the ratio of the same area at $5 \mathrm{~h}$ after $\mathrm{NaAsO}_{2}$ exposure, which was set at 100 .

To count cells expressing $\mathrm{mKO} 2$ and $\mathrm{mAG}$, we used the monochromatic color images for each fluorescent protein, which were obtained every $8 \mathrm{~h}$ from $1 \mathrm{~h}$ after initiation of $\mathrm{NaAsO}_{2}$ exposure. After counting the number of $\mathrm{mKO} 2$ - and $\mathrm{mAG}-$ expressing cells, the value at each time point was then calibrated using the number of cells in the same area at $1 \mathrm{~h}$ after $\mathrm{NaAsO}_{2}$ exposure, which was set at 100 .

To analyze cell fate after $\mathrm{S}$ phase entry, the digital images of $\mathrm{mKO} 2, \mathrm{mAG}$, and bright field, which were obtained from astrocytes with or without exposure to $4 \mu \mathrm{M} \mathrm{NaAsO}$, were merged at each time point. The merged images at all-time points were then saved as a movie file to observe temporal changes in the expression of $\mathrm{mKO} 2$ and $\mathrm{mAG}$, and the morphology of target cells. Target cells were astrocytes that expressed mAG at $41 \mathrm{~h}$ in the control group and at $9 \mathrm{~h}$ in the $\mathrm{NaAsO}_{2}$-exposed group after initiation of $\mathrm{NaAsO}_{2}$ exposure, because the population of $\mathrm{mAG}$-expressing cells at these time points was the largest during live imaging for each group. These cells were traced until the end of live imaging to determine their viability. Live cells were defined as cells that expressed mAG followed by expression of mKO2 with normal morphology. Dead cells were defined as cells that expressed mAG followed by loss of fluorescent signals with abnormal morphology. A total of 434 cells in the control group and 426 cells in the $\mathrm{NaAsO}_{2}$-exposed group were followed up to determine their cell fate. For each group, the total cell number was defined as $100 \%$, and the percentages of live and dead cell populations were calculated.

\section{Analysis of GFAP Gene Copy Numbers Exposure to $\mathrm{NaAsO}_{2}$ and DNA Extraction}

Astrocytes originating from the cerebral cortex of $\mathrm{C} 57 \mathrm{BL} / 6 \mathrm{~J}$ mice were incubated in culture medium containing $\mathrm{NaAsO}_{2}$ at concentrations of $0,1,2$, or $4 \mu \mathrm{M}$ for $73 \mathrm{~h}$. The astrocytes were then rinsed in Dulbecco's phosphate-buffered saline without calcium and magnesium, and collected in microcentrifuge tubes by scraping the culture plates filled with the buffer. After centrifugation $(10,000 \mathrm{rpm}, 10 \mathrm{~min})$, the resulting cell pellet was subjected to extraction of total DNA with a DNeasy blood and tissue kit (Qiagen, Hilden, Germany). DNA samples were obtained from eight independent primary cultures derived from different animals.

\section{Real-Time PCR}

Real-time PCR was performed using a LightCycler 96 (Roche Diagnostics, Mannheim, Germany). To prepare standard samples for the GFAP gene, a partial fragment of the mouse GFAP gene (430 bp from 13,801 to $14,230 \mathrm{nt}$ ) was cloned by insertion of the DNA fragment into the pCR2.1-TOPO vector supplied in a TOPO TA cloning kit (Invitrogen). The plasmid vector containing a copy of the GFAP gene was serially diluted with nuclease-free water at $3.2 \times 10^{4}, 8.0 \times 10^{3}$, $2.0 \times 10^{3}, 5.0 \times 10^{2}$, and $1.25 \times 10^{2}$ copies per $2 \mu \mathrm{l}$. Two microliters of the standards and unknown samples containing total DNA extracted from the cultured cells were amplified in a $20 \mu \mathrm{l}$ reaction mixture containing $200 \mathrm{nM}$ of each primer (forward: 5'-TCCTTTCCACCTCCGCTAAC-3'; reverse: $5^{\prime}$ GTTGGGTCTTGCCTGTCTTC-3') and $10 \mu \mathrm{l}$ of $2 \times$ SYBR Premix Ex Taq (Takara Bio, Otsu, Japan). Real-time PCR conditions were initial activation of Taq polymerase for $30 \mathrm{~s}$ at $95^{\circ} \mathrm{C}$, followed by 40 cycles of $5 \mathrm{~s}$ at $95^{\circ} \mathrm{C}$ for denaturation, and then $30 \mathrm{~s}$ at $60^{\circ} \mathrm{C}$ for annealing and extension with a temperature transition rate of $20^{\circ} \mathrm{C} / \mathrm{s}$. After real-time PCR, melting curve analysis was carried out to demonstrate the specificity of the PCR product (estimated amplicon size: $138 \mathrm{bp}$ ), resulting in a melting curve with a single peak (data not shown). After measurement of the GFAP gene copy number in each sample, the values were expressed as a percentage of the value obtained from cells without $\mathrm{NaAsO}_{2}$ exposure, whose viability was set at $100 \%$.

\section{Apoptosis Assay}

Primary cultured astrocytes originating from the cerebral cortex of C57BL/6J mice were subjected to serum starvation (see Section Fluorescence Microscopy of Fucci-Expressing Astrocytes) to synchronize the cell cycle and then incubated in culture medium containing $\mathrm{NaAsO}_{2}$ at concentrations of 0,2 , or $4 \mu \mathrm{M}$ for $72 \mathrm{~h}$. The effects of $\mathrm{NaAsO}_{2}$ on DNA fragmentation was examined using a Cell Death Detection ELISA Plus Assay kit (Roche Diagnosis) in accordance with the manufacturer's protocol. This assay was performed using six independent primary cultures derived from different animals. The amount of nucleosomes 
generated from DNA fragmentation is expressed as relative to that in the controls, which was set at $100 \%$ for each culture derived from the same animal.

\section{Analysis of mRNA Levels Exposure to $\mathrm{NaAsO}_{2}$, RNA Extraction, and Reverse Transcription}

Primarily cultured astrocytes were subjected to serum starvation (see Section Fluorescence Microscopy of Fucci-Expressing Astrocytes) to synchronize the cell cycle and then exposed to 0 or $4 \mu \mathrm{M} \mathrm{NaAsO} \mathrm{O}_{2}$ in culture medium for 9 and $41 \mathrm{~h}$. After exposure, total RNA was extracted and purified with an RNeasy Mini kit (Qiagen) in accordance with the manufacturer's protocol. For each sample, total RNA (650 ng) was reverse transcribed into cDNA in a final reaction volume of $20 \mu \mathrm{l}$ using a PrimeScript RT Reagent kit (Takara Bio) in accordance with the manufacturer's protocol.

\section{Real-Time PCR}

To measure the gene expression levels of molecules involved in unscheduled S phase entry and apoptosis, p21, p53, E2F1, E2F4, and Gm36566, real-time PCR was performed using a LightCycler 96 (Roche Diagnostics). Equal amounts of cDNA from each sample were combined together and serially diluted with EASY dilution (Takara Bio) to prepare standard samples for each gene. One microliter of standards and diluted unknown samples were amplified in a $10 \mu \mathrm{l}$ reaction mixture containing $5 \mu \mathrm{l}$ of $2 \times \mathrm{SYBR}$ Premix Ex Taq (Takara Bio) and $100 \mathrm{nM}$ of each primer for specific genes (see Table 1). The real-time PCR settings were the same as those described in Section Real-Time PCR. The amounts of the mRNAs for target genes in each sample were normalized to the mRNA level of the housekeeping gene cyclophilin B (CPB) in the same sample. The normalized mRNA level of each target gene was expressed relative to that in the controls, which was set at $100 \%$. The percentage values were averaged from five different primary cultures.

\section{Statistical Analysis}

Two-way factorial analysis of variance (ANOVA) for repeated measures was used to examine the effects of $\mathrm{NaAsO}_{2}$ and

TABLE 1 | Primer sequences used for real-time PCR.

\begin{tabular}{|c|c|c|c|}
\hline & $\begin{array}{l}\text { Forward primer } \\
\text { sequence }\left(5^{\prime}-3^{\prime}\right)\end{array}$ & $\begin{array}{l}\text { Reverse primer } \\
\text { sequence }\left(5^{\prime}-3^{\prime}\right)\end{array}$ & $\begin{array}{l}\text { NCBI reference } \\
\text { sequence }\end{array}$ \\
\hline p21 & $\begin{array}{l}\text { TAGCTCCTTCCCTGG } \\
\text { GATTC }\end{array}$ & $\begin{array}{l}\text { ATAGCAAAGGGGCAG } \\
\text { AAAAG }\end{array}$ & AF035683 \\
\hline p53 & $\begin{array}{l}\text { GCTTCTCCGAAGACT } \\
\text { GGATG }\end{array}$ & $\begin{array}{l}\text { GTCCATGCAGTGAGG } \\
\text { TGATG }\end{array}$ & AB020317 \\
\hline Gm36566 & $\begin{array}{l}\text { TCCCATTCCCCTATC } \\
\text { TGTGT }\end{array}$ & $\begin{array}{l}\text { GCTATTCTCTGCTCC } \\
\text { GATCC }\end{array}$ & XM_011247417 \\
\hline E2F1 & $\begin{array}{l}\text { ACTGTGACTTTGGGG } \\
\text { ACCTG }\end{array}$ & $\begin{array}{l}\text { CAGAGGGTATGGATC } \\
\text { GTGCT }\end{array}$ & L21973 \\
\hline E2F4 & $\begin{array}{l}\text { CTGGCACTTGTGACT } \\
\text { GTGCT }\end{array}$ & $\begin{array}{l}\text { AGCACCACCСTCTCT } \\
\text { CTGAA }\end{array}$ & NM_148952 \\
\hline CPB & $\begin{array}{l}\text { AGACTGTTCCAAAAA } \\
\text { CAGTGGA }\end{array}$ & $\begin{array}{l}\text { GATGCTCTITCCTCC } \\
\text { TGTGC }\end{array}$ & M60456 \\
\hline
\end{tabular}

time on the $\mathrm{mAG} / \mathrm{mKO} 2$ emission ratio. One-way ANOVA was performed to determine the difference among groups with respect to the number of cells expressing $\mathrm{mAG}$ and $\mathrm{mKO} 2$, the copy number of the GFAP gene, and the amount of nucleosomes generated from DNA fragmentation. When significant overall effects were detected by one-way ANOVA, the Tukey-Kramer test was used for post-hoc analysis. Two-way ANOVA was performed to determine the effects of concentrations and exposure time of $\mathrm{NaAsO}_{2}$ on the mRNA levels of target genes. Differences in the populations of live and dead cells between groups with or without exposure to $\mathrm{NaAsO}_{2}$ were analyzed by the nonparametric Mann-Whitney $U$-test.

\section{RESULTS}

\section{Immunoreactivity of GFAP in Cultured Cells}

Microscopy and counting DAPI-stained cells with or without GFAP immunoreactivity showed that most DAPI-stained cells exhibited GFAP-immunoreactive signals (98 $\pm 0.4 \%$ in four primary cultures derived from different animals; Figure 1). Thus, cells that were isolated from the mouse brains and cultured in vitro were astrocytes expressing GFAP.

\section{Cell Cycle Distribution of Fucci-Expressing Astrocytes}

Most primary cultured astrocytes from the cerebral cortex of Fucci tg mice expressed $\mathrm{mKO} 2$ after their cell cycles were synchronized by serum starvation (Figure 2A). mAG-expressing astrocytes emerged at $12 \mathrm{~h}$ after synchronization of the cell cycle. Forty-two hours after synchronization was the first time that expression of $\mathrm{mAG}$ reached a peak. mAG expression then decreased and the second peak of mAG expression occurred at $66 \mathrm{~h}$ after synchronization. This cycle of $\mathrm{mAG}$ expression was repeated during fluorescence microscopic observation.

The emission ratio of $\mathrm{mAG}$ to $\mathrm{mKO} 2$ in Fucci-expressing astrocytes changed over time (Figure 2B). The $\mathrm{mAG} / \mathrm{mKO} 2$ emission ratio was low until $12-18 \mathrm{~h}$ after synchronization of the

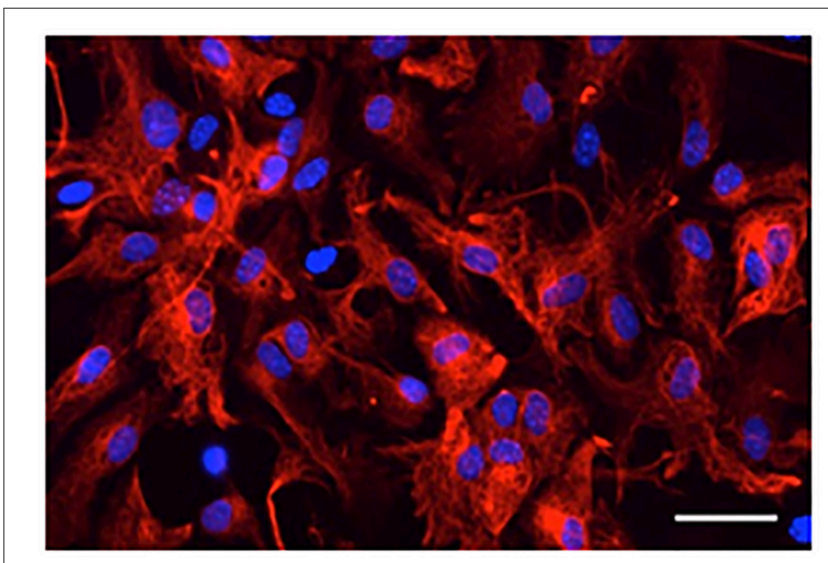

FIGURE 1 | Digital photomicrograph of primary cultured astrocytes. Astrocytes were immunostained for GFAP (red) and counterstained with DAPI (blue). Scale bar: $50 \mu \mathrm{m}$. 
A

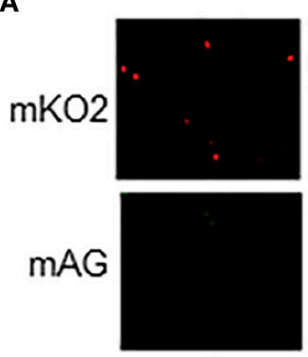

0
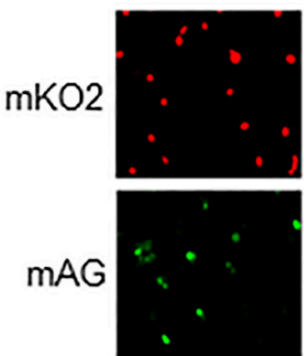

36
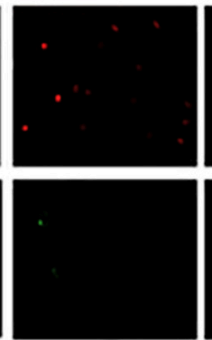

6
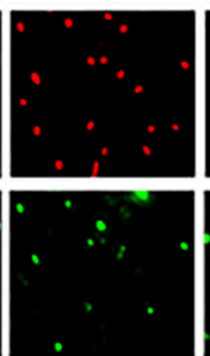

42

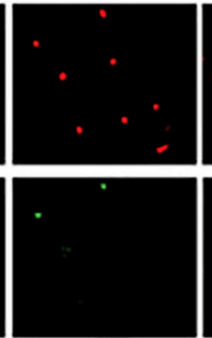

12
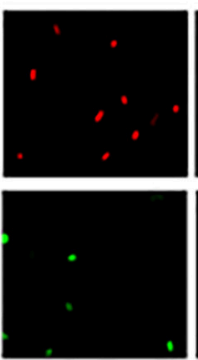

48
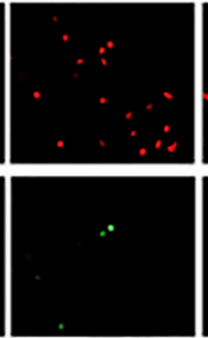

18
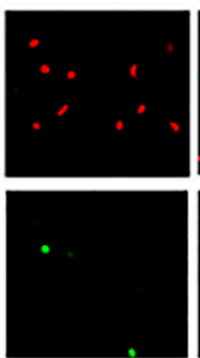

54
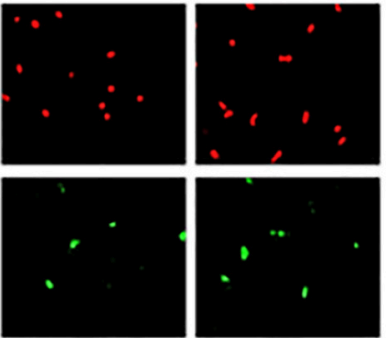

24
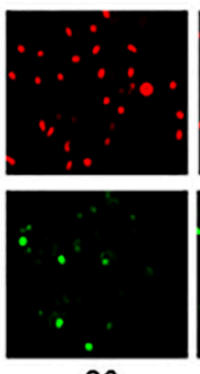

60
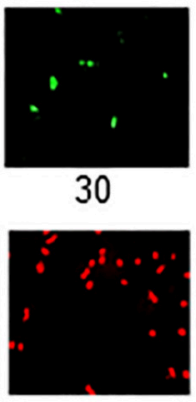

30

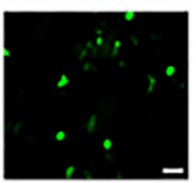

66

Time after synchronization of cell cycle $(\mathrm{h})$

B

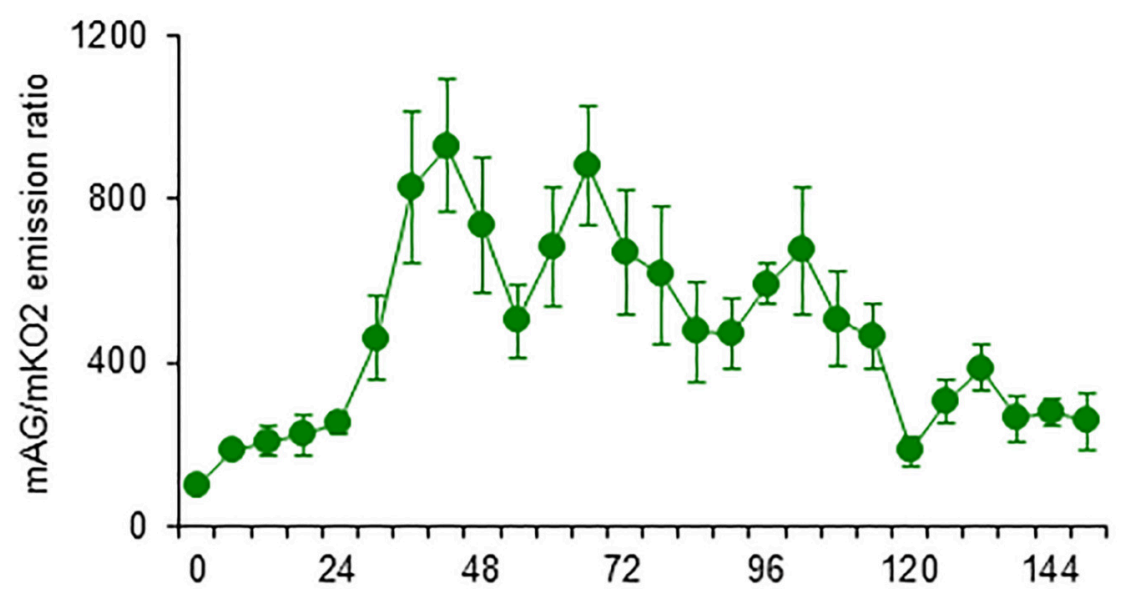

Time after synchronization of cell cycle (h)

FIGURE 2 | Temporal changes in $\mathrm{mAG}$ and $\mathbf{m K O} 2$ emission signals of Fucci-expressing astrocytes. After astrocytes were serum starved for $72 \mathrm{~h}$ to synchronize the cell cycle, they were cultured in medium containing 10\% FBS and applied to cell cycle monitoring. (A) Time-lapse images of mAG and mKO2 emission signals after the original fluorescent colors were converted to pseudocolors (mAG, green; mKO2, red). Scale bar: $50 \mu \mathrm{m}$. (B) Temporal changes in the $\mathrm{mAG} / \mathrm{mKO} 2$ emission ratio of Fucci-expressing astrocytes. All data points are the means \pm standard error of the mean (SEM) of four primary cultures derived from different animals. The $\mathrm{mAG} / \mathrm{mKO} 2$ emission ratio at each time point was calibrated using the ratio at $0 \mathrm{~h}$ after the cells were cultured in $10 \%$ FBS-containing medium, which was set at 100 .

cell cycle. The ratio dramatically increased from 24 to $42 \mathrm{~h}$ after synchronization of the cell cycle and then decreased until $54 \mathrm{~h}$ after synchronization. The ratio increased again and reached a peak at $66 \mathrm{~h}$ after synchronization of the cell cycle in four primary cultures derived from different animals. The cyclic changes in the $\mathrm{mAG} / \mathrm{mKO} 2$ emission ratio were observed four times during the analysis period. The mean interpeak interval of the $\mathrm{mAG} / \mathrm{mKO} 2$ emission ratio for each culture was $30,28,32$, and $30 \mathrm{~h}$. When these values were represented as the cell cycle duration in each culture, the mean of four different experiments was $30 \pm$ $0.82 \mathrm{~h}$, indicating that the cell cycle duration of Fucci-expressing astrocytes is $\sim 30 \mathrm{~h}$.

\section{Effects of $\mathrm{NaAsO}_{2}$ on the Cell Cycle of Astrocytes}

Fucci-expressing astrocytes mostly emitted mKO2 fluorescence signals at the beginning of live imaging with or without $\mathrm{NaAsO}_{2}$ exposure, while little emission of mAG signals was 
observed (Figure 3; Supplementary Movies 1-4). In control and $\mathrm{NaAsO}_{2}$ (1 and $2 \mu \mathrm{M}$ )-exposed groups, astrocytes emitting $\mathrm{mAG}$ fluorescence signals were frequently observed between 33 and $49 \mathrm{~h}$ after initiation of $\mathrm{NaAsO}_{2}$ exposure, which then decreased over time. On the other hand, in astrocytes exposed to $4 \mu \mathrm{M}$ $\mathrm{NaAsO}_{2}$, mAG fluorescence signals were found at 5-9 h after $\mathrm{NaAsO}_{2}$ exposure. In some astrocytes exposed to $4 \mu \mathrm{M} \mathrm{NaAsO}_{2}$, the fluorescent emissions of $\mathrm{mAG}$ and $\mathrm{mKO} 2$ had disappeared after 31 h of exposure to $\mathrm{NaAsO}_{2}$.

Two-way ANOVA for repeated measures indicated that the temporal changes in the $\mathrm{mAG} / \mathrm{mKO} 2$ emission ratio differed significantly among groups $\left[F_{(3,175)}=49.3, p<0.05 \times\right.$ $\left.10^{-26}\right]$, over time $\left[F_{(34,175)}=2.91, p<0.000005\right]$, and by interactions between the main factors $\left[F_{(102,525)}=1.84\right.$, $p<0.00001]$. In control and $\mathrm{NaAsO}_{2}(1$ and $2 \mu \mathrm{M})$-exposed groups, the $\mathrm{mAG} / \mathrm{mKO} 2$ emission ratio was low and maintained a stable level until $23 \mathrm{~h}$ after $\mathrm{NaAsO}_{2}$ exposure, which then increased over time and reached a peak at 39-45 h after $\mathrm{NaAsO}_{2}$ exposure, followed by a gradual decrease until the end of live imaging (Figure 4). The peak levels of the $\mathrm{mAG} / \mathrm{mKO} 2$ emission ratio in $\mathrm{NaAsO}_{2}$ (1 and $2 \mu \mathrm{M}$ )-exposed groups were lower than those in the control group. The temporal change in the $\mathrm{mAG} / \mathrm{mKO} 2$ emission ratio of the $\mathrm{NaAsO}_{2}(4 \mu \mathrm{M})$-exposed group was different from that of other groups. In the $\mathrm{NaAsO}_{2}$ $(4 \mu \mathrm{M})$-exposed group, a peak of the $\mathrm{mAG} / \mathrm{mKO} 2$ emission ratio was found at $7 \mathrm{~h}$ after initiation of $\mathrm{NaAsO}_{2}$ exposure, whereas no obvious peak in the ratio was observed when the ratio showed a peak in the control and $\mathrm{NaAsO}_{2}(1$ and $2 \mu \mathrm{M})$-exposed groups.

\section{Effects of $\mathrm{NaAsO}_{2}$ on the Number of Fucci-Expressing Astrocytes}

In control and $\mathrm{NaAsO}_{2}(1 \mu \mathrm{M})$-exposed groups, the numbers of mAG-expressing cells at 33 and $41 \mathrm{~h}$ after $\mathrm{NaAsO}_{2}$ exposure were larger than those at other time points for each group (Figure 5A). Compared with the control group, the number of mAG-expressing cells was significantly $(p<0.05)$ smaller at $41 \mathrm{~h}$ after $\mathrm{NaAsO}_{2}$ exposure in the $\mathrm{NaAsO}_{2}(2 \mu \mathrm{M})$-exposed group

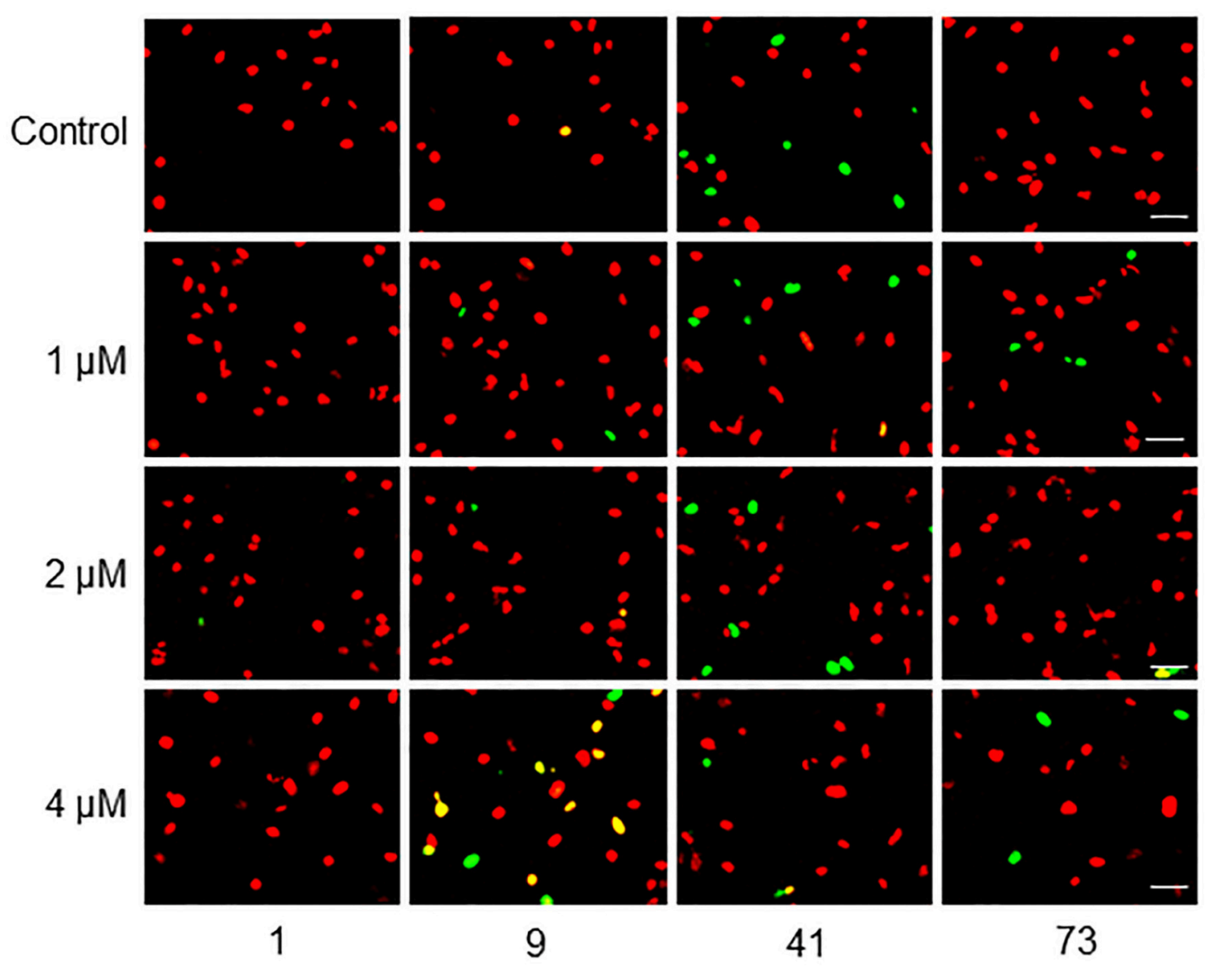

Time after initiation of $\mathrm{NaAsO}_{2}$ exposure (h)

FIGURE 3 | Time-lapse images of Fucci-expressing astrocytes after initiation of $\mathbf{N a A s O}_{2}$ exposure. Images of $m A G$ and mKO2 signals were merged after the original colors were converted to pseudocolors ( $\mathrm{mAG}$, green; $\mathrm{mKO} 2$, red). Images were obtained from Fucci-expressing astrocytes exposed to $\mathrm{NaAsO}_{2}$ at concentrations of 0 (control), 1, 2, or $4 \mu \mathrm{M}$ for 1-73h. Scale bar: $50 \mu \mathrm{m}$. 


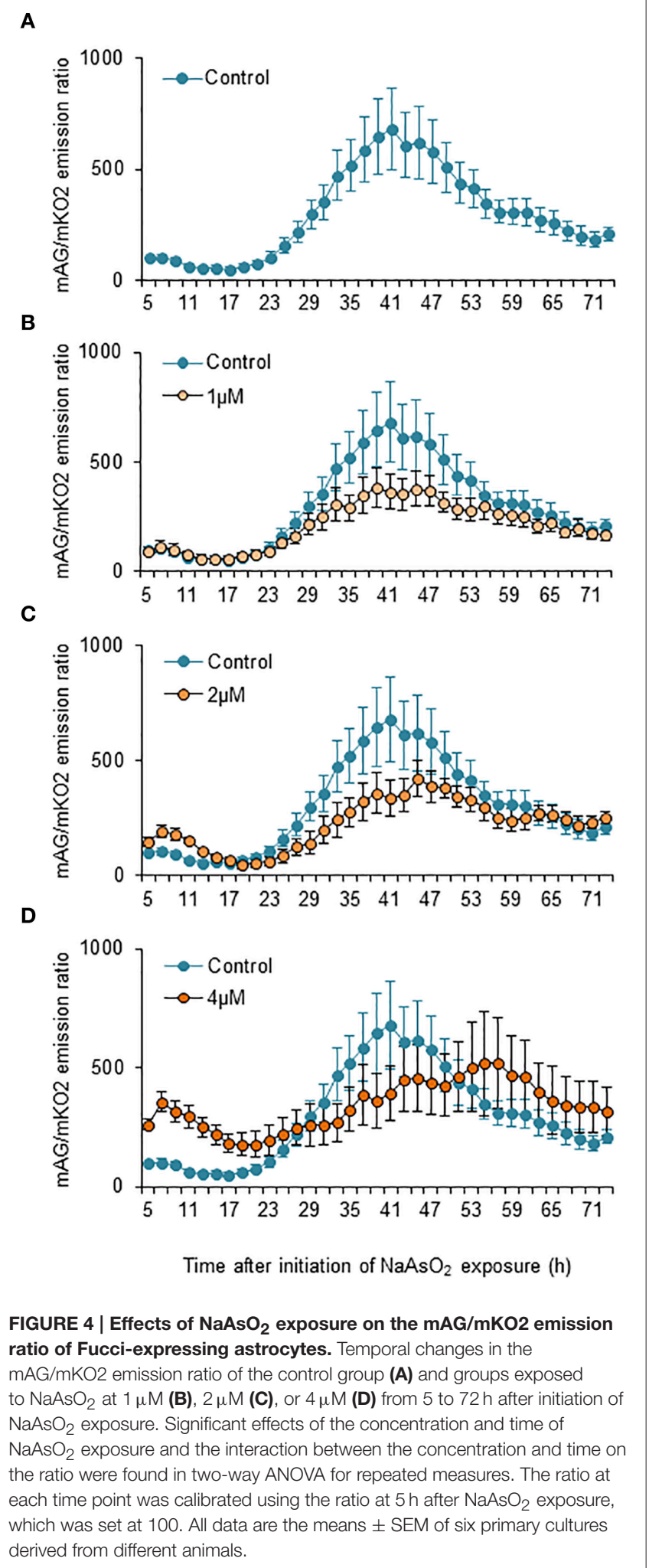

and at 25, 33, and $41 \mathrm{~h}$ after $\mathrm{NaAsO}_{2}$ exposure in the $\mathrm{NaAsO}_{2}$ $(4 \mu \mathrm{M})$-exposed group. In the $\mathrm{NaAsO}_{2}(4 \mu \mathrm{M})$-exposed group, the number of $\mathrm{mAG}$-expressing cells was highest at $9 \mathrm{~h}$ after
$\mathrm{NaAsO}_{2}$ exposure, which was significantly $(p<0.05)$ larger than that in the control group.

There was tendency toward an increase in the number of cells expressing $\mathrm{mKO} 2$ from the beginning to the end of live imaging in control and $\mathrm{NaAsO}_{2}(1 \mu \mathrm{M})$-exposed groups (Figure 5B). At 57,65 , and $73 \mathrm{~h}$ after $\mathrm{NaAsO}_{2}$ exposure, the total number of mKO2-expressing cells showed a concentration-dependent decrease, although there was no significant difference in the number of $\mathrm{mKO} 2$-expressing cells among the groups at each time point.

\section{Effects of $\mathrm{NaAsO}_{2}$ on Cell Death after S Phase Entry}

To analyze cell fate after $S$ phase entry, we traced Fucciexpressing astrocytes that emitted $\mathrm{mAG}$ fluorescence signals at $41 \mathrm{~h}$ in the control group and at $9 \mathrm{~h}$ after initiation of $\mathrm{NaAsO}_{2}$ exposure in the $\mathrm{NaAsO}_{2}(4 \mu \mathrm{M})$-exposed group. As a result, most cells in the control group were alive at the end of live imaging, because the fluorescent emission signals changed from $\mathrm{mAG}$ to $\mathrm{mKO} 2$, and the morphology was normal (Figure 6A). Conversely, in most astrocytes of the $\mathrm{NaAsO}_{2}(4 \mu \mathrm{M})$-exposed group, the emission signal of $\mathrm{mAG}$, which was observed at $9 \mathrm{~h}$ after $\mathrm{NaAsO}_{2}$ exposure, had disappeared by the end of live imaging (Figure 6B). In addition, the cells did not express $\mathrm{mKO} 2$ and exhibited abnormal morphology with a debris-like structure. The population of live cells after $\mathrm{S}$ phase entry was significantly $(p<0.01)$ larger in the control group than in the $\mathrm{NaAsO}_{2}$ $(4 \mu \mathrm{M})$-exposed group (Figure $6 \mathrm{C}$ ). In contrast, the population of dead cells after S phase entry was significantly $(p<0.01)$ larger in the $\mathrm{NaAsO}_{2}$-exposed group than in the control group.

\section{Effects of $\mathrm{NaAsO}_{2}$ on the Copy Number of the GFAP Gene and DNA Fragmentation}

Exposure to $\mathrm{NaAsO}_{2}$ for $73 \mathrm{~h}$ significantly $\left[F_{(3,28)}=4.30, p<\right.$ 0.05 ] reduced the GFAP gene copy number in a concentrationdependent manner (Figure 7). The copy number of the GFAP gene in the $\mathrm{NaAsO}_{2}(4 \mu \mathrm{M})$-exposed group was significantly $(p<0.05)$ smaller than that in the control group. We found no significant effect of lower $\mathrm{NaAsO}_{2}$ concentrations.

The amount of nucleosomes generated from DNA fragmentation in astrocytes did not significantly $\left[F_{(1,15)}=2.21\right.$, $p=0.14]$ change after exposure to $\mathrm{NaAsO}_{2}(2$ and $4 \mu \mathrm{M})$ for 72 h (Figure 8).

\section{Effect of $\mathrm{NaAsO}_{2}$ on the mRNA Expression of Apoptotic Markers and Cell Cycle Regulators}

We did not find any significant effects of $\mathrm{NaAsO}_{2}$ exposure on the mRNA levels of E2F1, E2F4, Gm36566, p21, or p53 in astrocytes (Figure 9). The mRNA levels of E2F1, E2F4, and p21, but not Gm36566 and p53, changed over time after synchronization of the cell cycle of astrocytes. The mRNA levels of E2F1 $\left[F_{(1,16)}=\right.$ $\left.300.69, p<0.01 \times 10^{-9}\right]$ and $\mathrm{p} 21\left[F_{(1,16)}=37.74, p<0.00005\right]$ were significantly higher at $41 \mathrm{~h}$ than $9 \mathrm{~h}$ after synchronization of the cell cycle, while the mRNA levels of E2F4 $\left[F_{(1,16)}=16.28\right.$, $p<0.001]$ were higher at $9 \mathrm{~h}$ than $41 \mathrm{~h}$ after synchronization. 


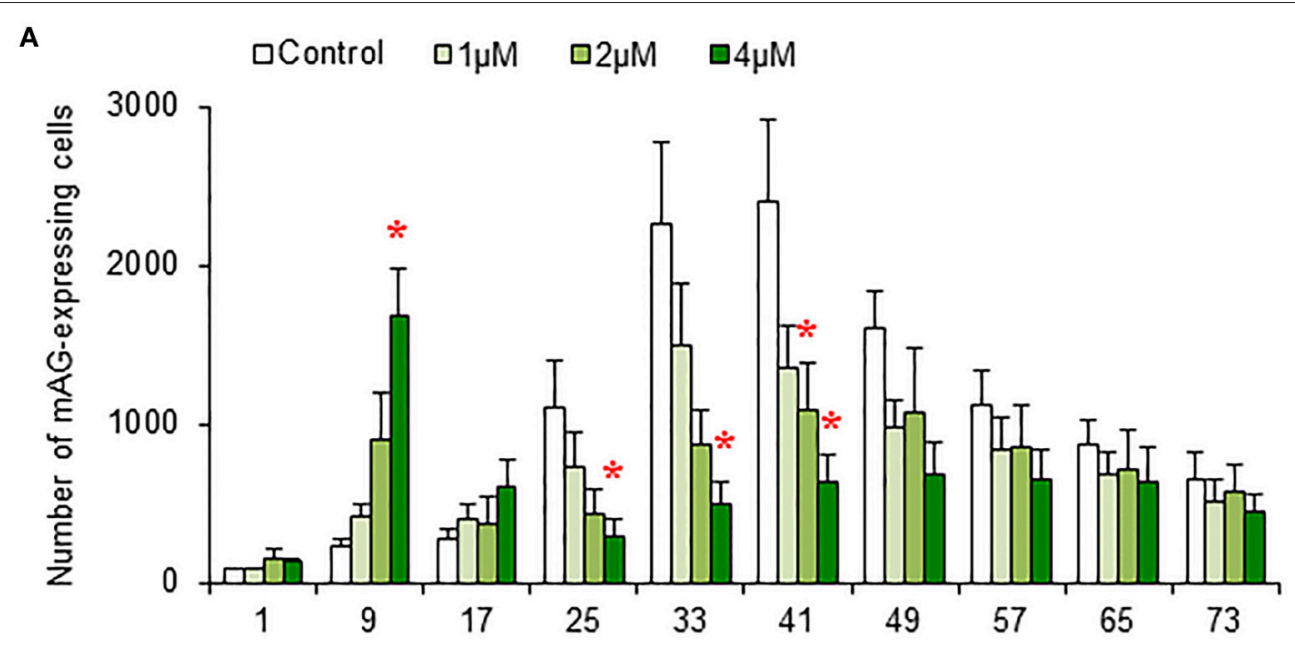

Time after initiation of $\mathrm{NaAsO}_{2}$ exposure (h)

B

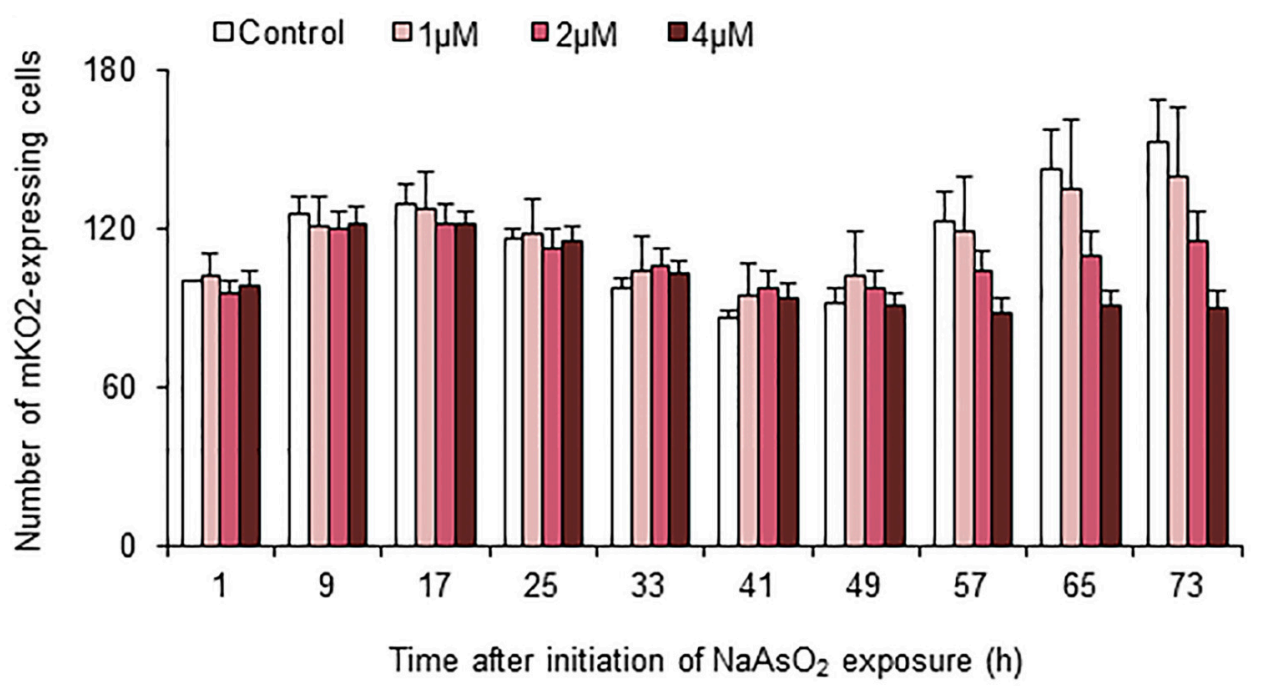

FIGURE 5 | Effects of $\mathrm{NaAsO}_{2}$ exposure on the number of Fucci-expressing astrocytes. The number of cells expressing mAG (A) and mKO2 (B) at the indicated time point after initiation of $\mathrm{NaAsO}_{2}$ exposure. The value for each time point was calibrated with the number of cells in the control group at $1 \mathrm{~h}$ after $\mathrm{NaAsO}$ exposure, which was set at 100. All data are the means \pm SEM of six primary cultures derived from different animals. ${ }^{*} p<0.05$ vs. control at the same time point.

\section{DISCUSSION}

There is serious concern about contamination of ground water with arsenic, because chronic consumption of arseniccontaminated water causes an impairment of cognitive functions (Calderon et al., 2001; Tsai et al., 2003; Wasserman et al., 2007). The World Health Organization recommends a limit of $0.01 \mathrm{mg} / \mathrm{L}(0.01 \mathrm{ppm}$ ) arsenic in water (World Health Organization, 2011). However, arsenic contamination in tube well water was found in Bangladesh at a concentration of more than $0.3 \mathrm{mg} / \mathrm{L}$ (0.3 ppm; Smith et al., 2000). In a native Andean population living in a part of Argentina, where drinking water contains arsenic at about $0.2 \mathrm{mg} / \mathrm{L}(0.2 \mathrm{ppm})$, the concentrations of arsenic were $9 \mu \mathrm{g} / \mathrm{L}$ in cord blood, $11 \mu \mathrm{g} / \mathrm{L}$ in maternal blood, $34 \mu \mathrm{g} / \mathrm{kg}$ in placenta, and $2.3 \mu \mathrm{g} / \mathrm{kg}$ in breast milk $(0.009,0.011,0.034$, and 0.0023 ppm, respectively; Concha et al., 1998a,b). According to a study measuring the accumulated levels of arsenic in newborn mice of mothers that were chronically exposed to $\mathrm{NaAsO}_{2}$ (10-80 ppm) during the gestational period via drinking water, the accumulated level of arsenic in the brain was higher than that in the liver and blood, and ranged from $\sim 100$ to $700 \mathrm{ng} / \mathrm{g}(0.1-$ 0.7 ppm; Markowski et al., 2011). We previously reported that $\mathrm{NaAsO}_{2}$ at $0.5-10 \mu \mathrm{M}$ induced cell death and suppressed neuritogenesis of cultured neurons (Koike-Kuroda et al., 2010; Aung et al., 2013; Maekawa et al., 2013). In this study, to examine whether $\mathrm{NaAsO}_{2}$ at the micromolar concentrations affect cultured astrocytes, we set the exposure concentrations 
A

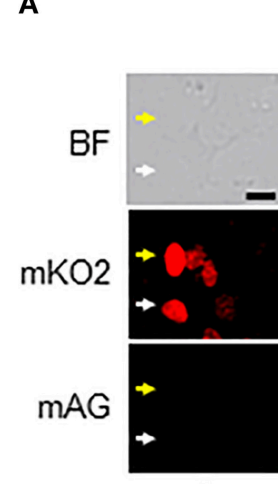

1

B

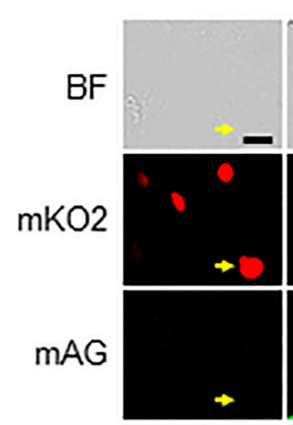

1

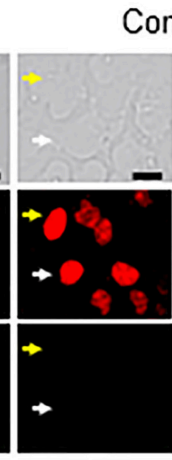

9

$\mathrm{NaAsO}_{2}(4 \mu \mathrm{M})$

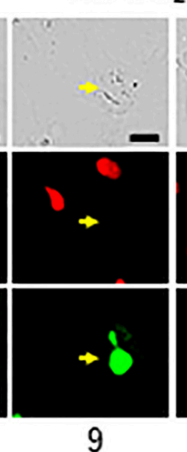

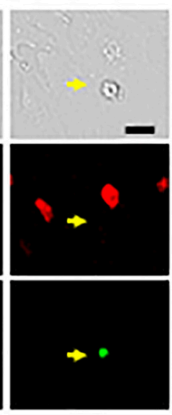

41
C
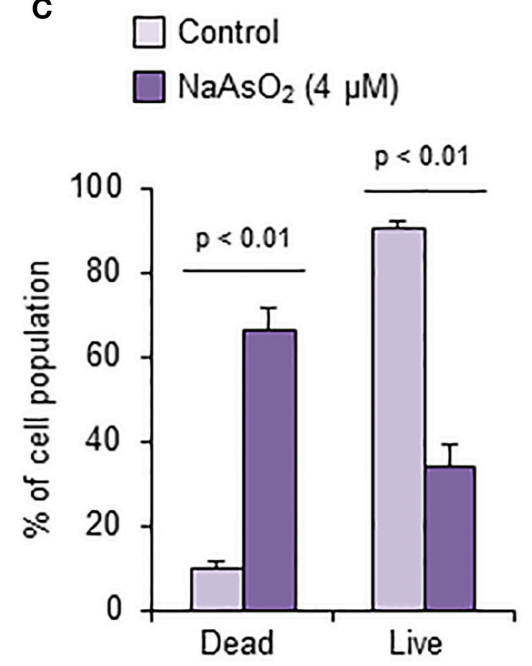

Time after initiation of $\mathrm{NaAsO}_{2}$ exposure (h)

FIGURE 6 | Effects of $\mathrm{NaAsO}_{2}$ exposure on cell fate after S phase entry. Digital photomicrograph of Fucci-expressing astrocytes captured with bright field (BF) and emission of $\mathrm{mKO} 2$ and $\mathrm{mAG}$ after pseudocolor conversion from the original fluorescent colors ( $\mathrm{mKO} 2$, red; $\mathrm{mAG}$, green) in control and $\mathrm{NaAsO} 2$ (4 $\mu \mathrm{M}$ )-exposed groups (A,B). Yellow and white arrows indicate the same cell or area. Scale bar: $20 \mu \mathrm{m}$. Cell population after Fucci-expressing cells entered $\mathbf{S}$ phase (C). The percentage values of dead and live cells after S phase entry were calculated with the total number of cells that entered S phase, which was set at $100 \%$. Values are the means \pm SEM of six primary cultures derived from different animals.

of $\mathrm{NaAsO}_{2}$ at 1,2 , and $4 \mu \mathrm{M}$ (equivalent to $0.129,0.258$, and $0.516 \mathrm{ppm}$, respectively), which were similar to environmental pollution levels and higher than human exposure levels by $~ 200-$ times or less.

It is known that cultured cells undergo phototoxic damage induced by frequent illumination with excitation light under a fluorescence microscope (Cervinka et al., 2008). Our previous study revealed that serum supplementation (the combination of $1 \%$ horse serum and $0.5 \%$ FBS) is vital to protect PC12 cells from phototoxic damage and enables live cell imaging without phototoxic damage (Koike-Kuroda et al., 2010). On the other hand, the doubling time of primary cultured astrocytes from the rat cerebral cortex is 6 days under the culture condition of $2 \%$ fetal calf serum (Geisert et al., 1996). This finding indicates that culturing astrocytes with serum supplementation at low concentrations is not beneficial for live imaging to monitor the cell cycle of astrocytes, because it requires a longer time (more than 6 days), which would increase the risk of phototoxic damage. Therefore, to promote cell proliferation and shorten the doubling time of astrocytes, we performed live imaging analysis of primary cultured Fucci-expressing astrocytes under the culture condition of $10 \%$ FBS. The duration of the cell cycle in Fucci-expressing astrocytes subjected to live imaging corresponded to that determined by fluorescence microscopy, suggesting that the live imaging technique in our current study could monitor the cell cycle without severe phototoxic damage.

Live imaging analysis of Fucci-expressing astrocytes showed that $\mathrm{NaAsO}_{2}$ exposure significantly altered the cell cycle. The cell population entering $S$ phase, when the cell population had reached to a peak level in the control group without $\mathrm{NaAsO}_{2}$ exposure, was decreased by $\mathrm{NaAsO}_{2}$ in a concentrationdependent manner. In contrast, the cell population entering unscheduled $\mathrm{S}$ phase at $9 \mathrm{~h}$ after initiation of $\mathrm{NaAsO}_{2}$ exposure was increased by $\mathrm{NaAsO}_{2}$ in a concentration-dependent manner. The findings in our current study suggest that $\mathrm{NaAsO}_{2}$ exposure disrupts the cell cycle and forces astrocytes to enter $\mathrm{S}$ phase at an unscheduled timing. In particular, $4 \mu \mathrm{M} \mathrm{NaAsO} 2$ had significant effects to disrupt cell cycle regulation and induce unscheduled S phase entry. Moreover, we traced the morphology 


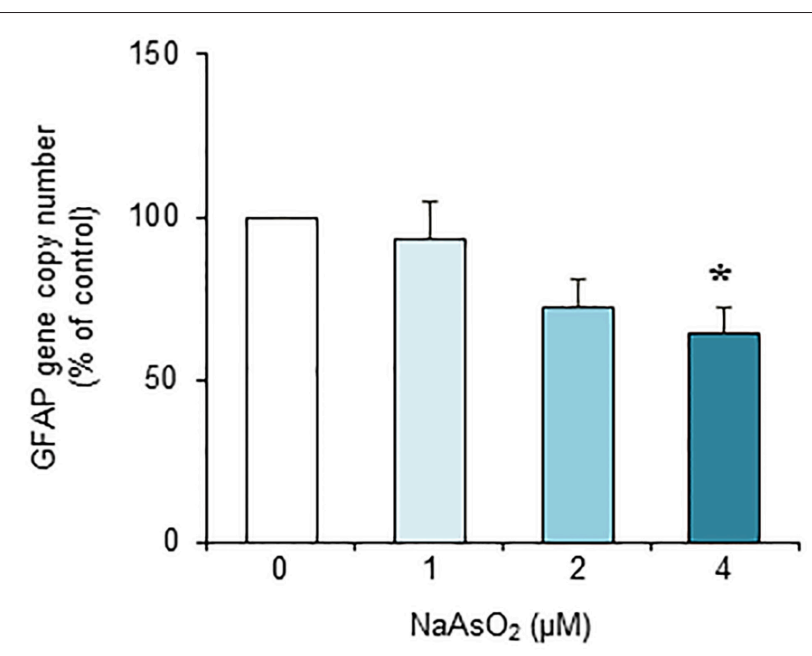

FIGURE 7 | Effects of $\mathrm{NaAsO}_{2}$ exposure on the copy number of the GFAP gene. The GFAP gene copy number is presented as a percentage of the control. Values are the means \pm SEM of eight primary cultures derived from different animals. ${ }^{*} p<0.05$ vs. control.

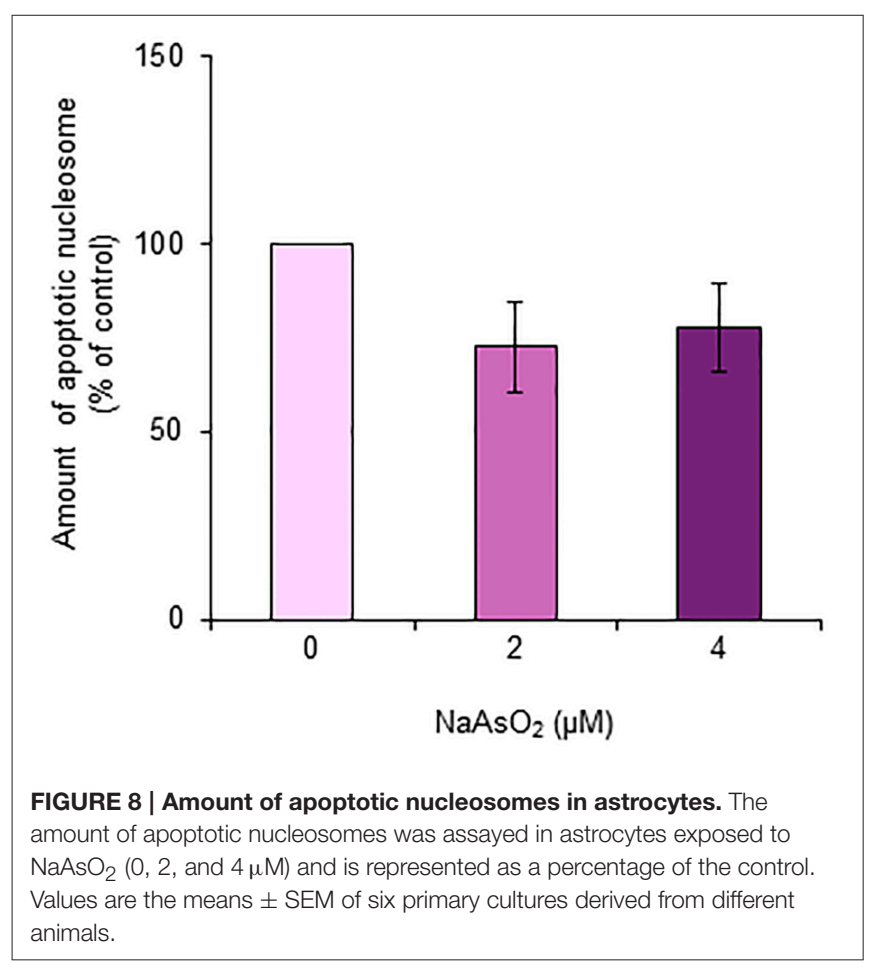

as well as $\mathrm{mKO} 2$ and $\mathrm{mAG}$ expression of Fucci-expressing astrocytes to determine the fate of astrocytes that underwent unscheduled $\mathrm{S}$ phase entry induced by $4 \mu \mathrm{M} \mathrm{NaAsO}$. As a result, more than $60 \%$ of astrocytes that entered $\mathrm{S}$ phase at $9 \mathrm{~h}$ after $\mathrm{NaAsO}_{2}$ exposure had died, with disappearance of fluorescent $\mathrm{mKO} 2$ and $\mathrm{mAG}$ signals, and transforming debrislike structures until the end of live imaging. We also measured the copy number of the GFAP gene at $73 \mathrm{~h}$ after $\mathrm{NaAsO}_{2}$ exposure, and found a significant decrease in the gene copy number induced by $4 \mu \mathrm{M} \mathrm{NaAsO}$. Taken together, it appears likely that $\mathrm{NaAsO}_{2}$ exposure at $4 \mu \mathrm{M}$ decreases the number of astrocytes by inducing unscheduled $S$ phase entry-coupled cell death. There is a report showing a slight increase in the viability of cultured rat cerebellar astrocytes by $\mathrm{NaAsO}_{2}$ exposure at $1 \mu \mathrm{M}$ for $24 \mathrm{~h}$, but higher concentrations (5-50 $\mu \mathrm{M})$ decrease the cell viability (An et al., 2016). In contrast, there is a report indicating that the cell viability is unaffected even when cultured rat astrocytes are exposed to $0.3 \mathrm{mM}$ arsenite for $8 \mathrm{~h}$, but it is decreased at $24 \mathrm{~h}$ after exposure (Koehler et al., 2014). Although the detailed mechanisms are largely unknown, arsenic may have dual effects to increase or decrease cell viability, which are dependent on the concentration and exposure time. Our current study supports the notion that arsenic decreases the viability of cultured astrocytes, and suggests that decreased cell viability is due to the reduction of cell number induced by unscheduled $S$ phase entry-coupled cell death.

It is well-known that unscheduled S phase entry is linked to apoptotic cell death after DNA damage (Dimova and Dyson, 2005; Cho and Liang, 2011). The live imaging analysis in our current study showed that the $\mathrm{mAG} / \mathrm{mKO} 2$ emission ratio and the number of $\mathrm{mAG}$-expressing cells increased faster with $\mathrm{NaAsO}_{2}$ exposure, indicating that up-regulation of geminin expression at an unscheduled timing is induced by $\mathrm{NaAsO}_{2}$ exposure. It has been reported that overexpression of geminin induces apoptotic cell death (Shreeram et al., 2002). In this context, we speculated that apoptosis is responsible for the unscheduled $S$ phase entry-coupled cell death induced by $\mathrm{NaAsO}_{2}$ exposure. To test this hypothesis, we examined the effects of $\mathrm{NaAsO}_{2}$ on the amount of nucleosomes generated from DNA fragmentation in astrocytes. However, in contrast to our expectations, we did not find any significant effect of $\mathrm{NaAsO}_{2}$ on the amount of nucleosomes generated from DNA fragmentation. In addition, we examined whether $\mathrm{NaAsO}_{2}$ exposure affected the expression levels of certain molecules involved in unscheduled $S$ phase entry and apoptosis. We measured the mRNA levels of $\mathrm{p} 53$, a principal regulator of apoptosis (Fridman and Lowe, 2003; Cho and Liang, 2011), E2F1, an S phase gene transcriptional activator and programed cell death inducer (Hou et al., 2000; Pardee et al., 2004; Dimova and Dyson, 2005; Lazzerini Denchi and Helin, 2005; Cho and Liang, 2011), E2F4, an S phase gene transcriptional suppressor (Dimova and Dyson, 2005), p21, a cyclin dependent kinase inhibitor (Cho and Liang, 2011) and unscheduled S phase inducer (Bedelbaeva et al., 2010), and Gm36566, the mouse ortholog of Killin, which acts as a S-phase-coupled apoptosis regulator (Cho and Liang, 2011). Considering the results of the apoptosis assay with reference to the amount of nucleosomes, the gene expression of these molecules was not significantly affected by $\mathrm{NaAsO}_{2}$ exposure, although the mRNA levels of E2F1, E2F4, and p21 had temporally changed with or without $\mathrm{NaAsO}_{2}$ exposure. Taken together, the unscheduled $\mathrm{S}$ phase entry that occurred in astrocytes after $\mathrm{NaAsO}_{2}$ exposure may be induced without alteration of the expression of these molecules. In addition, the subsequent cell death may be 


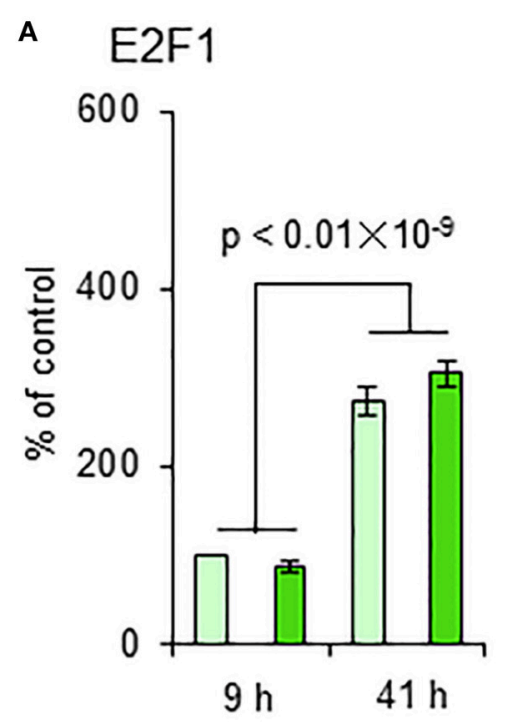

D $\quad$ P21

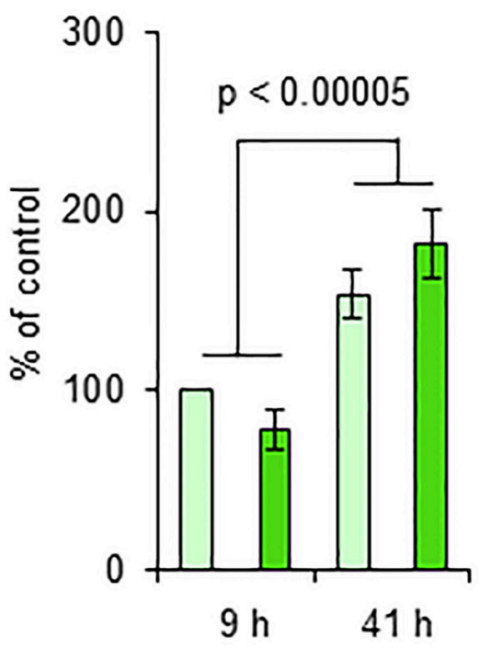

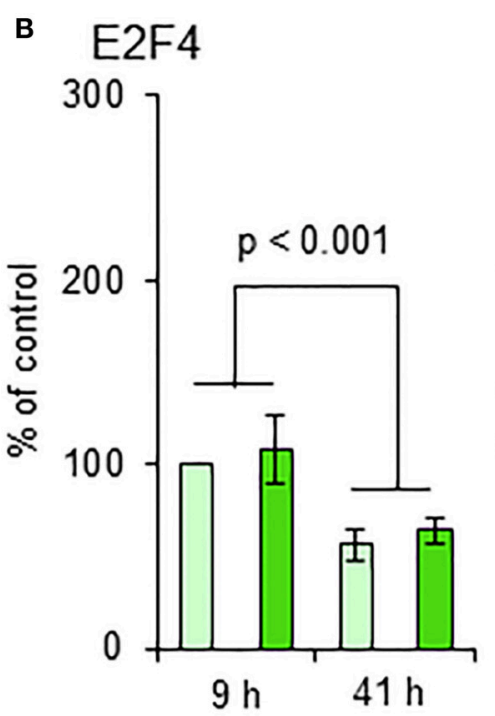
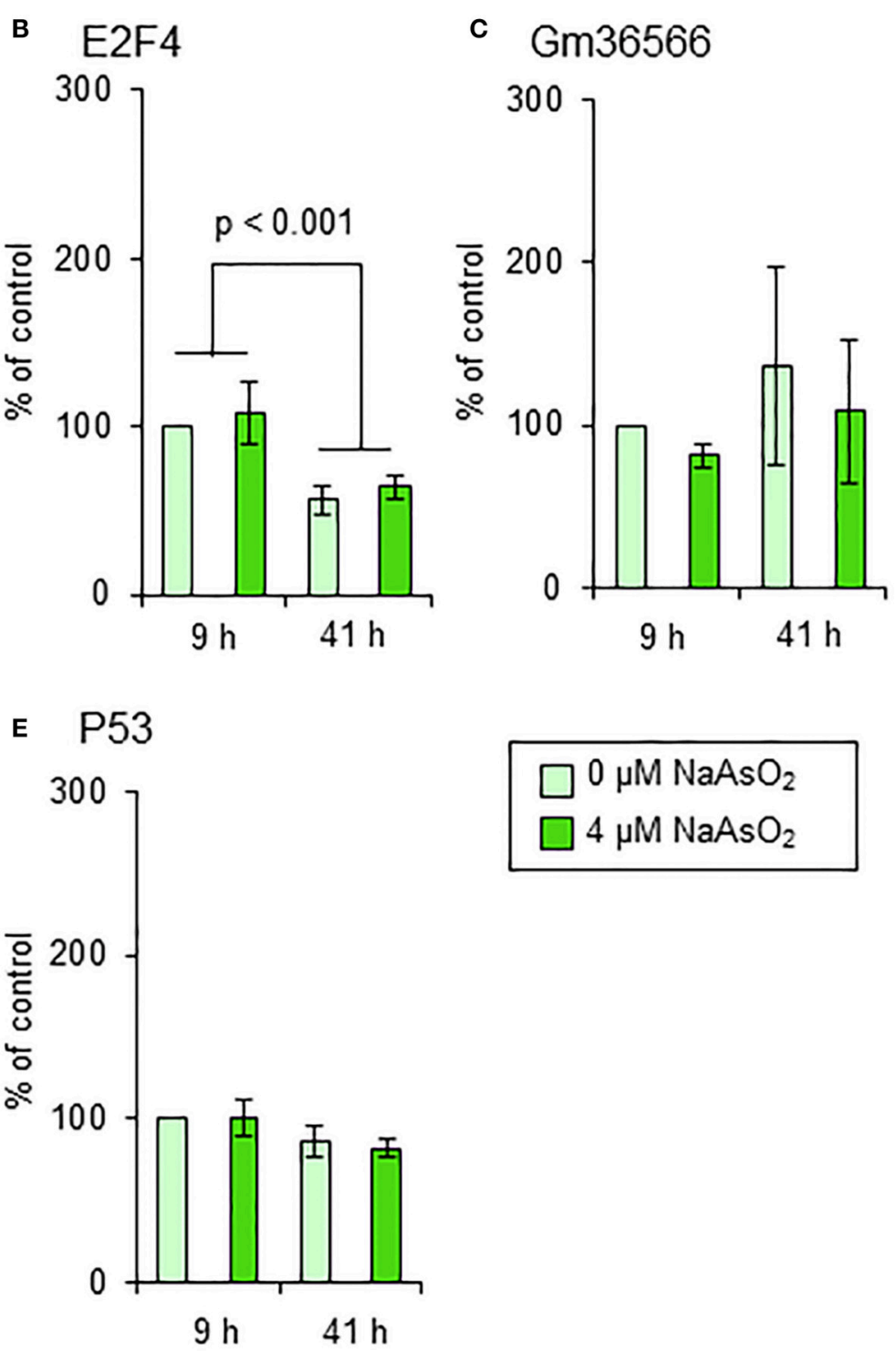

Time after synchronization of cell cycle and $\mathrm{NaAsO}_{2}$ exposure

FIGURE 9 | mRNA levels of E2F1 (A), E2F4 (B), Gm36566 (C), p21 (D), and p53 (E) in astrocytes. Astrocytes were exposed to $\mathrm{NaAsO}_{2}(0$ and $4 \mu \mathrm{M})$ for 9 and $41 \mathrm{~h}$. The mRNA level of each gene was normalized to that of CPB and are expressed relative to that of the control $(0 \mu \mathrm{M}$ for $9 \mathrm{~h})$, which was set at $100 \%$. Values are the means \pm SEM of five primary cultures derived from different animals.

caused by mechanisms other than apoptosis. However, the mechanisms were not determined in this study. Further studies are needed to clarify the molecular mechanisms of arsenic toxicity, which induce unscheduled $S$ phase entry-coupled cell death in astrocytes.

In summary, we examined the effects of $\mathrm{NaAsO}_{2}$ exposure on the cell cycle, viability, and apoptotic cell death of cultured mouse cerebral astrocytes. The results of these analyses suggest that $4 \mu \mathrm{M} \mathrm{NaAsO} \mathrm{O}_{2}$ significantly induces unscheduled $\mathrm{S}$ phase entry that is coupled with cell death by mechanisms other than apoptosis.

\section{AUTHOR CONTRIBUTIONS}

ST and FM designed the study; NH, HS, KS, and KA performed live imaging analyses; NH, HS, and SM performed molecular analyses; NH and ST wrote the manuscript; FM and MT critically revised the manuscript.

\section{FUNDING}

This study was supported by Grants-in-Aid for Scientific Research from the Ministry of Education, Culture, Sports, 
Science and Technology of Japan (23310043 and 15K14556 to ST; $24590307,15 \mathrm{~K} 08223$, and $15 \mathrm{~K} 14556$ to FM), grants from the National Institute for Environmental Studies [1011AF005 and 1416AT001] and a grant from the National Center for Child Health and Development (25-3) to FM.

\section{REFERENCES}

Abbott, N. J. (2002). Astrocyte-endothelial interactions and blood-brain barrier permeability. J. Anat. 200, 629-638. doi: 10.1046/j.1469-7580.2002.00064.x

An, Y., Liu, T., Liu, X., Zhao, L., and Wang, J. (2016). Rac1 and Cdc42 play important roles in arsenic neurotoxicity in primary cultured rat cerebellar astrocytes. Biol. Trace Elem. Res. 170, 173-182. doi: 10.1007/s12011-015-0456-7

Aung, K. H., Kurihara, R., Nakashima, S., Maekawa, F., Nohara, K., Kobayashi, T., et al. (2013). Inhibition of neurite outgrowth and alteration of cytoskeletal gene expression by sodium arsenite. Neurotoxicology 34, 226-235. doi: 10.1016/j.neuro.2012.09.008

Bedelbaeva, K., Snyder, A., Gourevitch, D., Clark, L., Zhang, X. M., Leferovich, J., et al. (2010). Lack of p21 expression links cell cycle control and appendage regeneration in mice. Proc. Natl. Acad. Sci. U.S.A. 107, 5845-5850. doi: 10.1073/pnas.1000830107

Calderon, J., Navarro, M. E., Jimenez-Capdeville, M. E., Santos-Diaz, M. A., Golden, A., Rodriguez-Leyva, I., et al. (2001). Exposure to arsenic and lead and neuropsychological development in Mexican children. Environ. Res. 85, 69-76. doi: 10.1006/enrs.2000.4106

Catanzaro, I., Schiera, G., Sciandrello, G., Barbata, G., Caradonna, F., Proia, P., et al. (2010). Biological effects of inorganic arsenic on primary cultures of rat astrocytes. Int. J. Mol. Med. 26, 457-462. doi: 10.3892/ijmm_00000485

Cervinka, M., Cervinkova, Z., and Rudolf, E. (2008). The role of timelapse fluorescent microscopy in the characterization of toxic effects in cell populations cultivated in vitro. Toxicol. In Vitro 22, 1382-1386. doi: 10.1016/j.tiv.2008.03.011

Cho, Y. J., and Liang, P. (2011). S-phase-coupled apoptosis in tumor suppression. Cell Mol. Life Sci. 68, 1883-1896. doi: 10.1007/s00018-011-0666-x

Concha, G., Vogler, G., Lezcano, D., Nermell, B., and Vahter, M. (1998a). Exposure to inorganic arsenic metabolites during early human development. Toxicol. Sci. 44, 185-190. doi: 10.1093/toxsci/44.2.185

Concha, G., Vogler, G., Nermell, B., and Vahter, M. (1998b). Low-level arsenic excretion in breast milk of native Andean women exposed to high levels of arsenic in the drinking water. Int. Arch. Occup. Environ. Health 71, 42-46. doi: 10.1007/s004200050248

Cotter, D. R., Pariante, C. M., and Everall, I. P. (2001). Glial cell abnormalities in major psychiatric disorders: the evidence and implications. Brain Res. Bull. 55, 585-595. doi: 10.1016/S0361-9230(01)00527-5

Dimova, D. K., and Dyson, N. J. (2005). The E2F transcriptional network: old acquaintances with new faces. Oncogene 24, 2810-2826. doi: 10.1038/sj.onc. 1208612

Frankel, S., Concannon, J., Brusky, K., Pietrowicz, E., Giorgianni, S., Thompson, W. D., et al. (2009). Arsenic exposure disrupts neurite growth and complexity in vitro. Neurotoxicology 30, 529-537. doi: 10.1016/j.neuro.2009.02.015

Fridman, J. S., and Lowe, S. W. (2003). Control of apoptosis by p53. Oncogene 22, 9030-9040. doi: 10.1038/sj.onc.1207116

Geisert, E. E. Jr., Yang, L., and Irwin, M. H. (1996). Astrocyte growth, reactivity, and the target of the antiproliferative antibody, TAPA. J. Neurosci. 16, 5478-5487.

Grandjean, P., and Landrigan, P. J. (2006). Developmental neurotoxicity of industrial chemicals. Lancet 368, 2167-2178. doi: 10.1016/S01406736(06)69665-7

Grandjean, P., and Landrigan, P. J. (2014). Neurobehavioural effects of developmental toxicity. Lancet Neurol. 13, 330-338. doi: 10.1016/S14744422(13)70278-3

Hou, S. T., Callaghan, D., Fournier, M. C., Hill, I., Kang, L., Massie, B., et al. (2000). The transcription factor E2F1 modulates apoptosis of neurons. J. Neurochem. 75, 91-100. doi: 10.1046/j.1471-4159.2000.0750091.x

\section{SUPPLEMENTARY MATERIAL}

The Supplementary Material for this article can be found online at: http://journal.frontiersin.org/article/10.3389/fnins. 2016.00297

Jin, Y., Sun, G., Li, X., Li, G., Lu, C., and Qu, L. (2004). Study on the toxic effects induced by different arsenicals in primary cultured rat astroglia. Toxicol. Appl. Pharmacol. 196, 396-403. doi: 10.1016/j.taap.2004.01.015

Jin, Y., Xi, S., Li, X., Lu, C., Li, G., Xu, Y., et al. (2006). Arsenic speciation transported through the placenta from mother mice to their newborn pups. Environ. Res. 101, 349-355. doi: 10.1016/j.envres.2005.11.006

Keim, A., Rossler, O. G., Rothhaar, T. L., and Thiel, G. (2012). Arsenite-induced apoptosis of human neuroblastoma cells requires $\mathrm{p} 53$ but occurs independently of c-Jun. Neuroscience 206, 25-38. doi: 10.1016/j.neuroscience.2012.01.001

Khammanit, R., Chantakru, S., Kitiyanant, Y., and Saikhun, J. (2008). Effect of serum starvation and chemical inhibitors on cell cycle synchronization of canine dermal fibroblasts. Theriogenology 70, 27-34. doi: 10.1016/j.theriogenology.2008.02.015

Koehler, Y., Luther, E. M., Meyer, S., Schwerdtle, T., and Dringen, R. (2014). Uptake and toxicity of arsenite and arsenate in cultured brain astrocytes. J. Trace Elem. Med. Biol. 28, 328-337. doi: 10.1016/j.jtemb.2014.04.007

Koike-Kuroda, Y., Kakeyama, M., Fujimaki, H., and Tsukahara, S. (2010). Use of live imaging analysis for evaluation of cytotoxic chemicals that induce apoptotic cell death. Toxicol. In Vitro 24, 2012-2020. doi: 10.1016/j.tiv.2010.07.022

Lazzerini Denchi, E., and Helin, K. (2005). E2F1 is crucial for E2F-dependent apoptosis. EMBO Rep. 6, 661-668. doi: 10.1038/sj.embor.7400452

Maekawa, F., Tsuboi, T., Oya, M., Aung, K. H., Tsukahara, S., Pellerin, L., et al. (2013). Effects of sodium arsenite on neurite outgrowth and glutamate AMPA receptor expression in mouse cortical neurons. Neurotoxicology 37, 197-206. doi: 10.1016/j.neuro.2013.05.006

Markowski, V. P., Currie, D., Reeve, E. A., Thompson, D., and Wise, J. P. Sr. (2011). Tissue-specific and dose-related accumulation of arsenic in mouse offspring following maternal consumption of arsenic-contaminated water. Basic Clin. Pharmacol. Toxicol. 108, 326-332. doi: 10.1111/j.1742-7843.2010.00660.x

Martinez, E. J., Kolb, B. L., Bell, A., Savage, D. D., and Allan, A. M. (2008). Moderate perinatal arsenic exposure alters neuroendocrine markers associated with depression and increases depressive-like behaviors in adult mouse offspring. Neurotoxicology 29, 647-655. doi: 10.1016/j.neuro.2008.05.004

Martinez-Finley, E. J., Ali, A. M., and Allan, A. M. (2009). Learning deficits in C57BL/6J mice following perinatal arsenic exposure: consequence of lower corticosterone receptor levels? Pharmacol. Biochem. Behav. 94, 271-277. doi: 10.1016/j.pbb.2009.09.006

Miller, F. D., and Gauthier, A. S. (2007). Timing is everything: making neurons versus glia in the developing cortex. Neuron 54, 357-369. doi: 10.1016/j.neuron.2007.04.019

Namgung, U., and Xia, Z. (2001). Arsenic induces apoptosis in rat cerebellar neurons via activation of JNK3 and p38 MAP kinases. Toxicol. Appl. Pharmacol. 174, 130-138. doi: 10.1006/taap.2001.9200

Niwa, H., Yamamura, K., and Miyazaki, J. (1991). Efficient selection for hightransfectants with a novel eukaryotic vector. Gene 108, 193-199.

Pardee, A. B., Li, C. J., and Reddy, G. P. (2004). Regulation in S phase by E2F. Cell Cycle 3, 1091-1094. doi: 10.4161/cc.3.9.1143

Rodriguez, V. M., Carrizales, L., Mendoza, M. S., Fajardo, O. R., and Giordano, M. (2002). Effects of sodium arsenite exposure on development and behavior in the rat. Neurotoxicol. Teratol. 24, 743-750. doi: 10.1016/S0892-0362(02)00313-6

Sakaue-Sawano, A., Kurokawa, H., Morimura, T., Hanyu, A., Hama, H., Osawa, H., et al. (2008). Visualizing spatiotemporal dynamics of multicellular cell-cycle progression. Cell 132, 487-498. doi: 10.1016/j.cell.2007. 12.033

Shreeram, S., Sparks, A., Lane, D. P., and Blow, J. J. (2002). Cell type-specific responses of human cells to inhibition of replication licensing. Oncogene 21, 6624-6632. doi: 10.1038/sj.onc. 1205910 
Smith, A. H., Lingas, E. O., and Rahman, M. (2000). Contamination of drinkingwater by arsenic in Bangladesh: a public health emergency. Bull. World Health Organ. 78, 1093-1103.

Tanaka, H., Tsukuma, H., and Oshima, A. (2010). Long-term prospective study of 6104 survivors of arsenic poisoning during infancy due to contaminated milk powder in 1955. J. Epidemiol. 20, 439-445. doi: 10.2188/jea.JE200 90131

Tsai, S. Y., Chou, H. Y., The, H. W., Chen, C. M., and Chen, C. J. (2003). The effects of chronic arsenic exposure from drinking water on the neurobehavioral development in adolescence. Neurotoxicology 24, 747-753. doi: 10.1016/S0161813X(03)00029-9

Wang, Y., Zhao, F., Liao, Y., Jin, Y., and Sun, G. (2013). Effects of arsenite in astrocytes on neuronal signaling transduction. Toxicology 303, 43-53. doi: 10.1016/j.tox.2012.10.024

Wasserman, G. A., Liu, X., Parvez, F., Ahsan, H., Factor-Litvak, P., Kline, J., et al. (2007). Water arsenic exposure and intellectual function in 6-year-old children in Araihazar, Bangladesh. Environ. Health Perspect. 115, 285-289. doi: 10.1289/ehp.9501

World Health Organization (2011). Guidelines for Drinking-Water Quality, 4th Edn. Geneva: WHO press.

Wong, H. K., Fricker, M., Wyttenbach, A., Villunger, A., Michalak, E. M., Strasser, A., et al. (2005). Mutually exclusive subsets of BH3-only proteins are activated by the p53 and c-Jun $\mathrm{N}$-terminal kinase/c-Jun signaling pathways during cortical neuron apoptosis induced by arsenite. Mol. Cell Biol. 25, 8732-8747. doi: 10.1128/MCB.25.19.8732-8747.2005

Xi, S., Sun, W., Wang, F., Jin, Y., and Sun, G. (2009). Transplacental and early life exposure to inorganic arsenic affected development and behavior in offspring rats. Arch. Toxicol. 83, 549-556. doi: 10.1007/s00204-009-0403-5

Zhao, F., Liao, Y., Jin, Y., Li, G., Lv, X., and Sun, G. (2012). Effects of arsenite on glutamate metabolism in primary cultured astrocytes. Toxicol. In Vitro 26, 24-31. doi: 10.1016/j.tiv.2011.10.003

Zheng, W., Aschner, M., and Ghersi-Egea, J. F. (2003). Brain barrier systems: a new frontier in metal neurotoxicological research. Toxicol. Appl. Pharmacol. 192, 1-11. doi: 10.1016/S0041-008X(03)00251-5

Conflict of Interest Statement: The authors declare that the research was conducted in the absence of any commercial or financial relationships that could be construed as a potential conflict of interest.

Copyright (c) 2016 Htike, Maekawa, Soutome, Sano, Maejima, Aung, Tokuda and Tsukahara. This is an open-access article distributed under the terms of the Creative Commons Attribution License (CC BY). The use, distribution or reproduction in other forums is permitted, provided the original author(s) or licensor are credited and that the original publication in this journal is cited, in accordance with accepted academic practice. No use, distribution or reproduction is permitted which does not comply with these terms. 